\title{
Metastatik Renal Hücreli Karsinom Tanılı Hastalarımızda Nötrofil Lenfosit Oranının Prognoz Üzerine Etkisi
}

\section{The Effect of Neutrophil Lymphocyte Ratio on Prognosis in Patients with Metastatic Renal Cell Carcinoma}

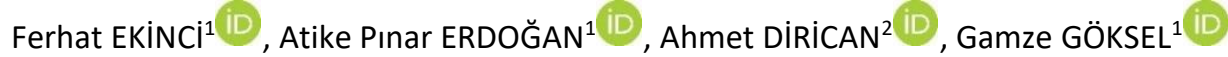 \\ ${ }^{1}$ Manisa Celal Bayar University, Medical Oncology Department, Manisa, Turkey \\ ${ }^{2}$ Izmir University of Economics, Medicalpark Hospital, Medical Oncology Department, Izmir, Turkey
}

\section{Öz}

GiRiş ve AMAÇ: Maliğn tümörlerle nötrofil lenfosit oranı (NLO) arasındaki prognostik ilişki bir çok kanserde araştırılmış ancak RHK hastalarında yeteri kadar çalışma olmadığı için kendi hastanemiz verilerinde bu hastalar ile NLO arasındaki prognostik ilişkiyi araştırılması amaçlanmıştır.

YÖNTEM ve GEREÇLER: Metastatik RHK tanılı 38 hastanın kayıtları retrospektif olarak incelendi. Hastalarda NLO eşik değerinin belirlenmesi için ROC analizi yapıldı ve testten çıkan sonuca göre hastalar $\mathrm{NLO}<2,14$ ve $\mathrm{NLO} \geq 2,14$ olmak üzere iki gruba ayrıldı. İki grup, hastalığa özgü sağ kalım açısından karşılaştırıldı.

BULGULAR: Tüm hastalarda hesaplanan genel sağ kalım 52 ay (\% $95 \mathrm{Cl}: 35-68$, std:6,5) olarak saptandı. NLO'da eşik değer belirleyebilmek için yapılan ROC analizinde elde edilen 2,14 cut off değerinden düşük olan $(<2,14) 14$ (\% 36,8) hastada ortalama sağ kalım (OS) 89 ay iken, yüksek olan $(>2,14) 24(\% 63,2)$ hastada ise OS 21 ay saptanmış ve bu sonuç istatistiksel olarak anlamlı $(p ; 0,03)$ raporlanmıştır.

TARTIŞMA ve SONUÇ: NLO, RHK'de OS ile ilişkili olabilir. Bununla birlikte, rutin kullanımlarını belirlemek için daha fazla çalışmaya intiyaç vardır.

Anahtar Kelimeler: Renal hücreli karsinom, nötrofil lenfosit oranı, prognoz

\section{Abstract}

INTRODUCTION: The prognostic relationship between malignant tumors and neutrophil lymphocyte ratio (NLR) has been investigated in many cancers, but since there are not enough studies in RCC patients, it was aimed to investigate the prognostic relationship between these patients and NLR in our own hospital data.

METHODS: Records of 38 patients diagnosed with metastatic RCC were analyzed retrospectively. ROC analysis was performed to determine the threshold value of NLR in patients and according to the result of the test, the patients were divided into two groups as NLR $<2.14$ and NLR $>2.14$. The two groups were compared in terms of disease-specific survival.

RESULTS: Overall survival calculated in all patients was 52 months (95\% Cl: 35-68, std: 6.5). In 14 (36.8\%) patients who were lower than the 2.14 cut off value $(<2.14)$ obtained in the ROC analysis performed to determine the threshold value in the NLR, the mean survival (OS) was 89 months, while the higher $(>2,14)$ In $24(63.2 \%)$ patients, OS was detected for 21 months, and this result was reported to be statistically significant ( $p ; 0.03)$.

DISCUSSION and CONCLUSION: NLR may be OS related in RCC. However, more studies are needed to determine their routine use.

Keywords: Renal cell carcinoma, neutrophil to lymphocyte ratio, prognosis

\section{INTRODUCTION}

Renal cell carcinoma (RCC) constitutes $2-3 \%$ of all cancers. Today, almost half of these tumors are detected incidentally $(1,2)$. Although many chemical substances have been blamed in the etiology, smoking is still the most important risk factor. RCC is resistant to chemotherapy and radiotherapy and therefore nephrectomy is the only curative treatment. $(1,3)$. Again, as in many cancers, many histological types, tumor diameter, stage, surgical margins, nuclear grade, lymphovascular invasion, metastasis, proliferation markers and clinical factors (patient performance status, anemia) have been defined in RCC cases $(4,5)$.

Inflammation plays an important role in the development of many cancers by stimulating angiogenesis in tumor cells (TH). It has been 
shown that an increased number of neutrophils in the peripheral blood as a result of the hematopoietic response created by active cytokines produced by $\mathrm{TH}$, result in progression of a more malignant tumour pattern $(4,6)$. Since the response of leukocytes to stress causes an increase in neutrophil count and a decrease in lymphocyte count, the ratio of these two subgroups to each other is used as an inflammation marker in clinical practice (6).

The prognostic relationship between malignant tumors and the neutrophil-lymphocyte ratio (NLR) has been investigated in many cancers, but as there are insufficient studies of RCC patients, the aim of this study was to investigate the prognostic relationship between these patients and NLR in our own hospital data.

\section{METHODS}

A retrospective analysis was made of the data of 38 patients who were followed up in the Medical Oncology Clinic of Manisa Celal Bayar University between November 2010 and July 2017. Approval for the study was granted by the hospital Ethics Committee (decision no: 20.478.486, dated: 27.11.2019). Gender, age, comorbidity, diagnosis stage, metastasis locations, treatments received, and the neutrophil and lymphocyte values of the patients were recorded. ROC analysis was performed to determine the threshold value of NLR in the patients. According to the ROC analysis, the patients were separated into two groups as NLR $<2.14$ and NLR> 2.14. The two groups were compared in terms of overall survival. The

patients were separated into 3 groups according to the risk classification of the international RCC database community (IMDC) (Table 2). Survival analysis was applied to these 3 groups (Figure 1 ).

\section{Statistical analysis:}

Data obtained in the study were analyzed statistically using SPSS vn.18.0 software.
Comparisons between the groups were made using the t-test, Chi-square and Fisher's exact tests. Kaplan-Meier analysis was used to determine disease-specific survival and overall survival. A value of $p<0.05$ was considered statistically significant.

Tablo 1. : Patient characteristics

\begin{tabular}{|c|c|c|}
\hline $\begin{array}{l}\text { Number of patients } \\
\text { (n) }\end{array}$ & & 38 \\
\hline $\begin{array}{l}\text { Average age average } \\
\text { (min-max) }\end{array}$ & & $59,71(21-78)$ \\
\hline \multirow[t]{2}{*}{ Gender (n) } & Male & 24 \\
\hline & Female & 14 \\
\hline \multirow[t]{3}{*}{ Smoking (n) } & Yes & 4 \\
\hline & No & 16 \\
\hline & Ex smoker. & 12 \\
\hline \multirow[t]{2}{*}{ Comorbidity } & $\begin{array}{l}\text { Have at least one } \\
\text { comorbidity. }\end{array}$ & 22 \\
\hline & $\begin{array}{l}\text { No history of } \\
\text { comorbidity. }\end{array}$ & 16 \\
\hline \multirow[t]{4}{*}{ 1st line treatment (n) } & Not receiving & 10 \\
\hline & İnterferon & 9 \\
\hline & Sunitinib & 15 \\
\hline & Pazopanib & 4 \\
\hline $\begin{array}{l}\text { Overall survival } \\
\text { (months) }\end{array}$ & & 52 \\
\hline \multirow[t]{2}{*}{ NLO } & $\begin{array}{l}\text { OS in those }<2.14 \\
\text { (n-months) }\end{array}$ & $14(89)$ \\
\hline & $\begin{array}{l}\text { OS in those }>2.14 \\
\text { (n-month) }\end{array}$ & $24(21)$ \\
\hline
\end{tabular}

Tablo 2. IMDC criteria and risk groups

\begin{tabular}{ll}
\hline Criteria \\
1 & Karnofsky performance state $<80 \%$ \\
2 & Hemoglobin below normal limits \\
3 & $<1$ year from diagnosis to treatment \\
4 & Above the upper limit of corrected calcium \\
5 & Platelets above the upper limit \\
6 & Neutrophil above the upper limit
\end{tabular}

\begin{tabular}{llll}
\hline $\begin{array}{l}\text { Number of } \\
\text { criteria }\end{array}$ & Risk group & $\begin{array}{l}\text { Number of } \\
\text { patients (n) }\end{array}$ & $\begin{array}{l}\text { OS } \\
\text { (months) }\end{array}$ \\
\hline 0 & Favorable & 2 & 89 \\
$1-2$ & Intermediate & 24 & 54 \\
$3-6$ & Poor & 12 & 9 \\
\hline
\end{tabular}

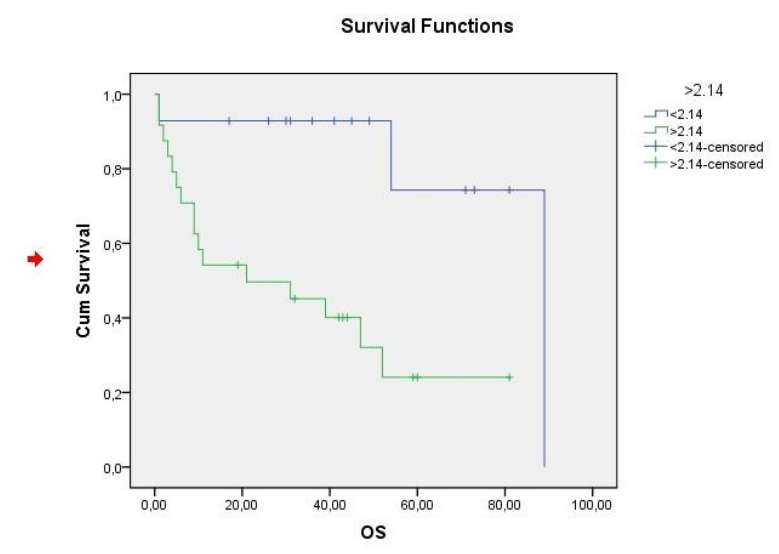

Figure 1. Survival Functions 


\section{RESULTS}

Evaluation was made of a total of 38 patients, comprising 24 (63.2\%) males and 14 (36.8\%) females with an average age of 59.71 years (range, 21- 78 years). At the end of the study period, $50 \%(n: 19)$ of the patients were alive and still under treatment and 50\% ( $\mathrm{n}: 19)$ had not survived.16 patients had never smoked, 12 were ex smokers, and 4 were active smokers. At least one comorbidity was determined in 22 patients, and the remaining 16 patients had no additional comorbid conditions. Following diagnosis, 10 patients did not receive any medical treatment. In treatment, interferon was given to $9(23.7 \%)$ patients, sunitinib to 15 (39.5\%), and pazopanib to $4(10.5 \%)$. Overall survival calculated for all patients was 52 months (95\% Cl: 35-68, std: 6.5). In 14 (36.8\%) patients with NLR below the cut off value of 2.14 obtained in the ROC analysis to determine the NLR threshold value, the mean survival (OS) was 89 months, and in the 24 (63.2\%) patients with NLR $>2.14$, OS was calculated as 21 months. This difference was statistically significant ( $p: 0.03)$. According to the IMDC risk classification, OS was reported as 89 months in 2 patients in the low-risk group, 54 months in 24 patients in the intermediate-risk group, and 9 months in 12 patients in the highrisk group.

\section{DISCUSSION}

The value obtained in the ROC analysis performed to determine the threshold value of the NLR was 2.14. While survival was calculated as 21 months in patients with NLR>2.14, this rate was found to be statistically significantly higher at 89 months in those with NLR <2.14 (p: 0.03). According to the IMDC risk classification, the OS was 89 months in the 2 patients in the low-risk group, 54 months in the 24 patients in the medium-risk group, and 9 months in

the 12 patients in the high-risk group. The data obtained are highly compatible with other data in the literature where the relationship between NLR and OS has been discussed.

As in many types of cancer, the effect of NLR in predicting prognosis has been shown in RCC patients. In 2014 this issue was made more visible with a very large meta-analysis of 100 studies and 40,559 patients was published which investigated the prognostic role of NLR in solid tumors (7). In this meta-analysis, the RCC series NLR, which included 8 studies and 1704 patients, reported RCC as the highest prognostic parameter after mesothelioma and pancreatic cancer ( $\mathrm{HR}=2.22 ; 95 \% \mathrm{Cl}=1.72$ to 2.88 ). This was concluded to be a guiding study on the reliability and applicability of inflammation markers in RCC, which is an immunogenic tumour type (7). Another study conducted on this subject was a meta-analysis of 15 studies in 2017 which included operable, inoperable and metastatic patients. The important point here is that NLR, which was examined pre-operatively ( 3 studies), was also determined as an independent prognostic indicator in showing disease recurrence (HR 1/4 $1.63[1.15,2.29])$. However, in locally advanced or metastatic disease, the prognostic value was found to be stronger in terms of predicting overall survival (HR 1.55 $[1.36,1.76])$, progression-free survival (HR $1 / 43.19$ $[2.23,4.57])$ and response to treatment (8). Similarly, another meta-analysis emphasizing the relationship of NLR with survival was published by Nunno et al. in 2018. A total of 2818 metastatic, and 1933 non metastatic patients were analyzed, and it was reported that high NLR resulted in shorter survival (HR; 2.05 (95\% Cl: 1.74-2.41) and HR; 1.57 (95\% Cl: 1.27-1.94).

Following the meta-analyses described above, a more recent study by Huszno et al. in 2019 included 141 patients diagnosed with metastatic RCC. Median OS was 7.8 months for those with a calculated NLR cut off value $>3.68$, and 36.1 months for those with NLR $<3.68$ ( $p<0.0001)$ (9). Having a high NLR rate predicts a very poor survival, as shown in the current study. Another 
contribution of this study to the literature is that survival analysis with neutrophil level is reported. A shorter OS was reported in patients with a higher neutrophil levels (8.0 vs 36.1 months, $p$ $<0.0001$ ). As mentioned in the Introduction of this paper, the main determinant of the NLR is the neutrophil level, because, as a result of the hemopoietic response created by cytokines produced by $\mathrm{TH}$, the number of neutrophils increases and this indicates that the tumor will have a more malignant pattern $(4,6,9)$.

One of the most recent studies emphasizing the prognostic importance of NLR resulted in the detection of a similar relationship in nonmetastatic tumours. In that study by Widz et al in

2020, a retrospective evaluation was made of the data of 196 patients who underwent nephrectomy between 2010 and 2012, and at a median 68-month follow-up there were seen to be fewer patients with a cut off NLR value $>2.69$ (n: 95, 48.5\%) than those with NLR <2.69 (n:101, $51.5 \%)$. Thus, the higher NLR indicated poorer survival $(p=0.006)$ and showed that NLR is not only prognostic in metastatic disease but also in the early stage (10). In the treatment of RCC, where conventional treatment options such as chemotherapy and radiotherapy are lacking, the course is rapidly evolving from targeted drugs to immunotherapies (IT) (11). The difference of these new drugs from many other options is that they direct immune system cells to tumor tissue (12). As RCC is an immunogenic tumor and as the treatment is based on the activation of immune system cells, it undoubtedly suggests that NLR is one of the best markers to be used at this stage. A fairly recent study of 65 diseases was presented by Suzuki et al in 2019. The progression-free survival was shorter for those with the calculated NLR cut off value $>5$ compared to those with NLR $<5$ (1.1 monthsvs.7.9 months). Similar results were seen of overall survival. While OS was 6 months in those with NLR $<5$, the median OS could not be reached in those with NLR $\geq 5$ ( $p$ $<0.001$ ) (13). In the current study, since only the 1st line treatments were noted, no additional analysis could be made in terms of the relationship between IT and NLR, and the limited number of patients makes this analysis difficult.

One of the most recent studies published in Turkey is a series of 331 multi-centered diseases by Hizal et al. The NLR cut-off value was calculated as 3 , and survival was reported as 11 months for those with NLR>3 and 32 months for those with NLR <3 (HR: 0.49 (95\% Cl 0.37-0.65), $p<0.001$ ) (14). Again, these data are important in terms of showing that a high NLR, which supports the current study and all the other studies mentioned, is associated with a worse survival. According to the IMDC risk classification, OS was 39, 28 and 7 months in 52 (low-risk group), 108 (medium-risk group), and 77 (high-risk group) patients, respectively. In the current study, the OS was 89 months for the 2 patients in the lowrisk group, 54 months in the 24 patients in the medium-risk group, and 9 months in the 12 patients in the high-risk group.

The main reason why NLR continues to be investigated both in malignant tumors other than RCC and in non-malignant diseases is to try to determine low-cost, accessible markers in terms of prognosis and the possible underlying etiologies to explain this relationship (15-17). The relationship between inflammation and tumorigenesis was first demonstrated by Virchow in the 19th century. This hypothesis has attracted attention with the presence of leukocytes in the tumor tissue and more frequent cancer in chronic inflammation regions (18). In the last 30

years, a substantial amount of data has been obtained to support this argument. In biopsies taken from patients with colon adenocarcinoma, increased neutrophil levels have been observed when compared with disease-free tissue, and in these samples, neutrophils have been found in abundance in tumor tissue, but their number was observed to increase in invasive and ulcerated 
areas (19). The same relationship has been seen with the demonstration that the lavage fluid taken from patients with bronchoalveolar carcinoma was higher in terms of neutrophil count than that taken from control subjects. Similarly, analyses have shown that neutrophilia is directly proportional to poor prognosis (20). Similar data have been obtained in many other cancers (21).

Inflammation mediators are important components of the tumor microenvironment. Especially in some cancers, oncogenic changes can induce an inflammatory microenvironment that promotes tumor development, or the inflammatory microenvironment may emerge before a change occurs in the tissue and create a predisposition to tumor formation (22). This environment also plays a role in angiogenesis or metastasis (8). At the same time, cancer tissue has a hypoxic microenvironment, leading to necrotic cell death in the tumor nucleus in hypoxic tissue and nutrient deficiency, leading to the release of proinflammatory cytokines from the tissue. Here, leukocytes that can be measured in the simplest form in peripheral blood and neutrophils, which are the most abundant representatives in proportion, represent this result $(23,24)$. However, although neutrophilia is observed in the response of leukocytes to stress, since there is a decrease in the lymphocyte count, the ratio of these two parameters in clinical practice leads to the use of these two parameters as a marker of inflammation, which was the basis of this study, the results of which were analyzed with reference to the literature.

The most important limitation of this study was the retrospective design and the low number of patients. In addition, there was no homogenization in patient characteristics and treatment groups.

\section{Conclusion:}

With the increase in studies on this subject, NLR will become strongly confirmed as an inexpensive, accessible and reliable parameter that can be used in many cancers and RCCs.

Informed Consent: Written consent was obtained from the participants.

Conflict of Interest: Authors declared no conflict of interest.

Financial Disclosure: Authors declared no financial support.

\section{REFERENCES}

1. Peinemann, F, Unverzagt, S, Hadjinicolaou, A. V., \& Moldenhauer, I. (2019). Immunotherapy for metastatic renal cell carcinoma: A systematic review. Journal of Evidence-Based Medicine, 12(4), 253-262.

2. Society AC. Cancer facts and figures. https://www.cancer.org/ research/cancer-factsstatistics/all-cancer-facts-figures/ cancer-facts-figures2017.html2017

3. Jonasch, E., Gao, J., \& Rathmell, W. K. (2014). Renal cell carcinoma. Bmj, 349, g4797.

4. Dirican, A, Kucukzeybek, Y, Erten, C., Somali, I., Demir, L., Can, A., ... \& Köseoglu, M. (2013). Prognostic and predictive value of hematologic parameters in patients with metastatic renal cell carcinoma: second line sunitinib treatment following IFN-alpha. Asian Pac J Cancer Prev, 14(3), 21015.

5. Roxburgh, C. S., \& McMillan, D. C. (2010). Role of systemic inflammatory response in predicting survival in patients with primary operable cancer. Future oncology, 6(1), 149-163.

6. Grivennikov, S. I., Greten, F. R., \& Karin, M. (2010). Immunity, inflammation, and cancer. Cell, 140(6), 883899.

7. Templeton, A. J., McNamara, M. G., Šeruga, B., VeraBadillo, F. E., Aneja, P., Ocaña, A., ... \& Tannock, I. F. (2014). Prognostic role of neutrophil-to-lymphocyte ratio in solid tumors: a systematic review and metaanalysis. JNCl: Journal of the National Cancer Institute, 106(6).

8. Boissier, R., Campagna, J., Branger, N., Karsenty, G., \& Lechevallier, E. (2017, April). The prognostic value of the neutrophil-lymphocyte ratio in renal oncology: A review. In Urologic Oncology: Seminars and Original Investigations (Vol. 35, No. 4, pp. 135-141). Elsevier.

9. Huszno, Joanna, et al. "The role of neutrophillymphocyte ratio, platelet-lymphocyte ratio, and platelets in the prognosis of metastatic renal cell carcinoma." Oncology 97.1 (2019): 7-17.

10. Widz, D., Mitura, P., Buraczynski, P., Plaza, P., Bar, M., Cabanek, M., ... \& Bar, K. (2020). Preoperative 
neutrophil-lymphocyte ratio as a predictor of overall survival in patients with localized renal cell carcinoma. Urology Journal, 17(1), 30-35.

11. Bilen MA, Dutcher GMA, Liu $Y$ et al (2018) Association between pretreatment neutrophil-to-lymphocyte ratio and outcome of patients with metastatic renal-cell carcinoma treated with nivolumab. Clin Genitourin Cancer 16(3): e563-e575

12. Motzer RJ, Escudier B, McDermott DF et al (2015) Nivolumab versus everolimus in advanced renal-cell carcinoma. New Engl J Med 373(19):1803-1813

13. Suzuki, K., Terakawa, T., Furukawa, J., Harada, K., Hinata, N., Nakano, Y., \& Fujisawa, M. (2020). Creactive protein and the neutrophil-to-lymphocyte ratio are prognostic biomarkers in metastatic renal cell carcinoma patients treated with nivolumab. International Journal of Clinical Oncology, 25(1), 135144.

14. Hizal, M., Sendur, M. A., Yasar, H. A., Bir Yucel, K., Arslan, C., Ucar, G., ... \& Bilgin, B. (2020). Neutrophillymphocyte ratio as a prognostic factor for survival in patients with advanced renal cell carcinoma (Turkish Oncology Group Study). Journal of Oncology Pharmacy Practice, 1078155219900908.

15. European Network of Cancer Registries: Eurocim version 4.0. 200: Lyon, France.

16. Kim SC, Sun KH, Choi DH, et al. Prediction of Long-Term Mortality Based on Neutrophil- Lymphocyte Ratio After Percutaneous Coronary Intervention. Am J Med Sci. 2016;351(5):467-72.

17. Quiros-Roldan E, Raffetti E, Donato F, et al. Neutrophil to Lymphocyte Ratio and Cardiovascular Disease Incidence in HIV-Infected Patients: A Population-Based Cohort Study. PLoS One. 2016;11(5): e0154900

18. Grivennikov, S. I., Greten, F. R., \& Karin, M. (2010). Immunity, inflammation, and cancer. Cell, 140(6), 883899.

19. Nielsen, B. S., Timshel, S., Kjeldsen, L., Sehested, M., Pyke, C., Borregaard, N., \& Danø, K. (1996). 92 kDa type IV collagenase (MMP-9) is expressed in neutrophils and macrophages but not in malignant epithelial cells in human colon cancer. International journal of cancer, 65(1), 57-62.

20. Bellocq, A., Antoine, M., Flahault, A., Philippe, C., Crestani, B., Bernaudin, J. F., ... \& Cadranel, J. (1998). Neutrophil alveolitis in bronchioloalveolar carcinoma: induction by tumor-derived interleukin- 8 and relation to clinical outcome. The American journal of pathology, 152(1), 83

21. Tazzyman, S., Lewis, C. E., \& Murdoch, C. (2009). Neutrophils: key mediators of tumour angiogenesis. International journal of experimental pathology, 90(3), 222-231.

22. Mantovani, A., Allavena, P., Sica, A., \& Balkwill, F. (2008). Cancer-related inflammation. nature,
454(7203), 436-444.

23. Sparmann, A., \& Bar-Sagi, D. (2004). Ras-induced interleukin-8 expression plays a critical role in tumor growth and angiogenesis. Cancer cell, 6(5), 447-458

24. Vakkila, J., \& Lotze, M. T. (2004). Inflammation and necrosis promote tumour growth. Nature Reviews Immunology, 4 